\title{
ANIMAL HEALTH SERVICES: EXTENT OF AVAILABILITY IN SOME SELECTED RURAL AREAS OF BANGLADESH
}

\section{H. Rahman ${ }^{1}$ and S. Rana ${ }^{2 *}$}

${ }^{1}$ Dept. of Agricultural Extension Education, Bangladesh Agricultural University, Mymensingh-2202, Bangladesh, ${ }^{2}$ Dept. of Agricultural Economics and Social Sciences, Chittagong Veterinary and Animal Sciences University, Khulsi, Chittagonj, Bangladesh

\begin{abstract}
The main objective of the study was to assess the nature and extent of availability of animal health services received by the rural livestock farmers. The research was conducted in four upazilas namely Companyganj of Sylhet, Modhukhali of Faridpur, Mathbaria of Pirojpur and Mithamoin of Kishoreganj districts. Data were collected by using both quantitative and qualitative methods from a sample of 480 farmers during April to September 2010.Almost all of the farmers had high level of availability of veterinary services in relation to treatment of diseases and availability of medicine. Only few (6 percent) received services regarding artificial insemination. Percentage of respondents receiving services on vaccination (32 percent) and surgery and obstetrics (22 percent) were also moderate. The MFTS project beneficiaries received all services with higher frequencies than those of the non-beneficiaries except from the availability of medicine.The farmers living near upazila headquarter received better services than those living far from the upazila headquarters.
\end{abstract}

Key words: Animal health services, availability, rural areas

\section{INTRODUCTION}

Livestock plays an important role in the national economy of Bangladesh with a direct contribution of $12 \%$ to agricultural GDP and 3\% to national economy (Bangladesh National Livestock Extension Policy, 2013) and providing 15\% of total employment in the economy (Bangladesh National Livestock Development Policy, 2007). The livestock sub-sector that includes poultry offers important employment and livelihood opportunities particularly for the rural poor, including the functionally landless, many of whom regard livestock as a main livelihood option. About 75 percent people rely on livestock to some extent for their livelihood, which clearly indicates that the poverty reduction potential of the livestock sub-sector is high (Tareque et al., 2010). Dairying is also considered a strong tool to develop a village micro economy of Bangladesh (Shamsuddin et al., 2007) in order to improve rural livelihoods and to alleviate rural poverty.

As a result of globalization and climate change the world is currently facing an unprecedented increase of emerging and re-emerging animal diseases and zoonoses (animal diseases transmissible to humans). Improving the governance of animal health service systems in both the public and private sector is one of the most effective responses to this alarming situation.

The availability and quality of animal health services can play a key role in increasing the productivity of the livestock sector (Umali et al., 1994).

The Government of Bangladesh is committed to take necessary steps to achieve self-sufficiency in milk, chicken and livestock production with a view to meet the protein demand of the nation (Bangladesh Economic Review, 2010). For such a goal to be materialized, proper importance should be given on the issues of animal health management and associated issues. As livestock sector marked the sign of sustained development in the last two decades, it is of utmost importance to secure proper veterinary service to the farmers whose livelihood depends on livestock to a large extent. There is a dearth of research based information on the extent of animal health services as received by the farming communities and the beneficiaries of present livestock health services. The study was undertaken in order to have an understanding of the above-mentioned issues with the objective: to determine the extent of availability of animal health services received by the rural livestock farmers in the study areas.

*Corresponding e-mail address: sohel_241@yahoo.com 


\section{S. Rana and M. H. Rahman}

\section{MATERIALS AND METHODS}

\section{Study areas}

The study was conducted in the operating areas under the Micro-Finance and Technical Support (MFTS) project as implemented by Palli-Karma Shayahak Foundation (PKSF). Four upazilas under four districts of Bangladesh were the specific locations. Those were Companyganj under Sylhet district, Modhukhali under Faridpur district, Mathbaria under Pirojpur district and Mithamoin under Kishoreganj district. The upazilas were selected as per advice of the Livestock Coordinator of MFTS project and the decision was finalized after preliminary visit and consultation with the officials of the concerned Partner NGOs of PKSF (known as PO) and Upazila Livestock Officers. In each upazila, two locations were selected for data collection. One of them was around the upazila headquarters, where official animal health services were easily available to the villagers and the other was a locality far from the upazila headquarters, from where it was difficult for the villagers to avail any type of services from the Upazila Veterinary Hospitals. In the present study, such remote villages were considered as distant study locations, which had poor communication infrastructures (road connections) to reach the upazila headquarters making it difficult to reach the hospitals in a short time.

\section{Population and sample of the study}

Data were collected from two different groups of farmers: MFTS project beneficiaries and their neighbours, who did not receive any support from MFTS project (hereinafter termed as non-beneficiaries). Therefore, the MFTS project beneficiaries of a specific upazila and their neighbours were the population of the study. However, beneficiaries of only two unions (near and far from upazila headquarters) and their upazilas were purposively selected as the study sample. The list of MFTS beneficiaries were collected from the concerned PKSF-POs. The total sample list has been presented in Table 1. A reserve list was prepared with $10 \%$ of the sample size to replace any member of the original sample in case of unavailability during interview.

Table 1 . The study locations and sample size for data collection

\begin{tabular}{llcc}
\hline $\begin{array}{l}\text { Upazila and } \\
\text { District }\end{array}$ & Study locations (villages and unions) & \multicolumn{2}{c}{ Sample size } \\
\cline { 2 - 3 } $\begin{array}{l}\text { Companyganj, } \\
\text { Sylhet }\end{array}$ & $\begin{array}{l}\text { Near: Kathalbari, Burdeo and Chanpur under Islampur union } \\
\text { Far: North Rajnagar, Shimultala and Diskibari under Ranikhali } \\
\text { and East Islampur unions } \\
\text { Modhukhali, } \\
\begin{array}{l}\text { Faridpur } \\
\text { beneficiaries }\end{array}\end{array}$ & 90 & 90 \\
$\begin{array}{l}\text { Mathbaria, } \\
\text { Perojpur }\end{array}$ & Far: Jahapur, Narikhali and Bakhsichadpur under Jahapur union & 45 & 45 \\
$\begin{array}{l}\text { Mithamoin, } \\
\text { Kishoreganj }\end{array}$ & $\begin{array}{l}\text { Near: Sabujnagar and Tikikata under Mathbaria union } \\
\text { Far: Gopdampur and Kalipur under Mithamoin union }\end{array}$ & 55 & 55 \\
\hline Total (480) & $\quad 50$ & 50 \\
\hline
\end{tabular}

\section{Measurement of focus variable}

The main focus of the study was to have an understanding of availability of animal health services to the villagers of the selected upazilas. Six aspects of animal health services were selected for this purpose. The aspects were: (i) disease diagnosis and treatment (ii) advice and general consultation on animal health and hygiene, (iii) surgery, obstetrics and gynecological services, (iv) disease prevention by vaccination, (v) availability of medicine (supply and purchase), and (vi) artificial insemination . The respondents were asked to indicate to what frequently a specific veterinary service was available in the locality when it was needed. A 4- 
point rated scale was used for each aspect of services while scores were assigned as per following manner: frequently available (assigned score-3), less frequently available (assigned score-2), rarely available (assigned

score-1), not at all available (assigned score-0).

Therefore, a Service Availability Index (SAI) of an aspect of animal health service was computed by summing the obtained weighted scores of all respondents and dividing the summated score by the number of respondents. The SAI could range from 0 to 3 , while the general interpretation of the score could be explained in the following way:

\begin{tabular}{|c|c|}
\hline $\begin{array}{lll}\text { Ranges of Service Availability } \\
\text { Index(SAI) }\end{array}$ & General interpretation \\
\hline 0 & Availability of no service in the locality as perceived by the respondents \\
\hline 0.1 to 1.0 & Low availability of service in the locality as perceived by the respondents \\
\hline 1.1 to 2.0 & $\begin{array}{l}\text { Moderate availability of service in the locality as perceived by the } \\
\text { respondents }\end{array}$ \\
\hline 2.1 to 3.0 & High availability of service in the locality as perceived by the respondents \\
\hline
\end{tabular}

\section{Data Collection}

Data were collected from the respondents in a number of ways. A number of focus group discussions (FGD) were conducted to have a preliminary understanding of the issues of the research. These FGD sessions were helpful to finalise the questionnaire (interview schedule) by collecting and confirming the items used in its different sections. Furthermore, two FGD sessions were conducted to verify the findings of the questionnaire survey. Apart from the research team members, some experts from the fields of animal production, especially the concerned Upazila Livestock Officers and Veterinary Surgeons made valuable contribution in the FGD sessions. Two FGDs were conducted in April, 2010 and the two verification FGDs were held in September, 2010.

In order to collect relevant data, a structured interview schedule was carefully prepared keeping the objectives of the study in mind. The schedule was pre-tested before final data collection and necessary modifications were made on the basis of pre-testing experience. Data were collected from the selected farmers by using the interview schedule during March to August, 2010. Face to face interviews were conducted from the selected farmers (project beneficiaries) and their neighbours (as indicated in Table 1) by two field enumerators. The field agents of the concerned POs of PKSF helped in organizing the interviews, most of which were taken in the respondents' village homes. Only a few numbers of the sampled farmers (seven out of 240 selected MFTS project beneficiaries) were not available during the interviewing, while alternate arrangements of interviews were made by drawing farmers from a reserve list.

\section{Data Processing and Analysis}

The collected data were systematically recorded, coded, compiled and analyzed in accordance with the objectives of the study. Descriptive analytical measures like frequency and percentage were used to describe and interpret the data.

\section{RESULTS AND DISCUSSION}

The major objective of the study was to have an understanding on availability of animal health services to the villagers. Data presented in Tables 2 and 3 show the extent of availability of six types of veterinary services in the study areas.

Availability of different types of veterinary services has been studied to different client groups (Table 2). Veterinary health services in relation to disease diagnosis and treatment including prescription has been received by MFTS project beneficiaries and non beneficiaries with highest frequency followed by availability of medicine (supply and purchase), advice and general consultation, disease prevention by vaccination, surgery, obstetrics and gynaecological services and artificial insemination (AI) which was the least frequency. This result indicated that A.I. and reproductive services were not available to the villagers those who were residing in the remote area. The frequency of veterinary services for disease prevention by vaccination, surgery, obstetrics and gynaecological services were also very low. It might be due to lack of knowledge about the benefit of those 
services or livestock office failed to convey the message of those benefit to the peoples were living in the remote area as livestock office did not have sufficient number of veterinarians with staffs and field assistant. It seems S. Rana and M. H. Rahman

that the MFTS project beneficiaries had relatively higher level availability of different types of veterinary health services, except from availability of medicine (supply and purchase). This result indicated that poor people (in the study, the project beneficiaries) cannot buy medicine as per need for the treatment as they live from hand to mouth.

Table 2. Availability of animal health services to different client groups

\begin{tabular}{|c|c|c|c|}
\hline \multirow[t]{2}{*}{ Aspects of veterinary services } & \multicolumn{3}{|c|}{$\begin{array}{c}\text { Service Availability Index (SAI) and percentage of respondents received } \\
\text { services }\end{array}$} \\
\hline & $\begin{array}{l}\text { MFTSP beneficiaries } \\
(\mathrm{N}=240)\end{array}$ & $\begin{array}{l}\text { Non beneficiaries } \\
(\mathrm{N}=240)\end{array}$ & Total $(\mathrm{N}=480)$ \\
\hline Disease diagnosis and treatment & $2.61(100 \%)$ & $2.40(99.7 \%)$ & $2.52(99.8 \%)$ \\
\hline Advice and general consultation & $1.78(72.5 \%)$ & $1.53(68.8 \%)$ & $1.67(70.9 \%)$ \\
\hline $\begin{array}{l}\text { Surgery, obstetrics and gynaecological } \\
\text { services }\end{array}$ & $0.37(26.9 \%)$ & $0.22(16.7 \%)$ & $0.30(22.4 \%)$ \\
\hline Disease prevention by vaccination & $0.62(34.0 \%)$ & $0.55(29.6 \%)$ & $0.59(32.1 \%)$ \\
\hline $\begin{array}{l}\text { Availability of medicine (supply and } \\
\text { purchase) }\end{array}$ & $2.62(100 \%)$ & $2.75(100 \%)$ & $2.68(100 \%)$ \\
\hline Artificial insemination & $0.09(6.8 \%)$ & $0.07(5.0 \%)$ & $0.08(6.0 \%)$ \\
\hline
\end{tabular}

Availability of different types of veterinary services was determined at near and far from upazila during one year study period (Table 3). Veterinary health services in relation to availability of medicine (supply and purchase) as received by the respondents around upazila and far from upazila had highest frequency followed by disease diagnosis and treatment including prescription, advice and general consultation, disease prevention by vaccination, surgery, obstetrics and gynaecological services and artificial insemination, which was had the least frequency. This result indicated that peoples were mostly interested in buying medicines from nearby market or stores for the treatment purpose, while they were relatively less interested to receive other forms of formal services from government or other available sources. All of the six aspects of veterinary services were found to have higher level of availability among the respondents living around upazila headquarter than those living far from upazila. This result indicated that the veterinary service was relatively easily accessible to the beneficiaries of short distances. On the other hand, peoples were not used to come frequently from far distance to take veterinary services in the Upazila Livestock Office and Hospital. The major reason is that it is not easy to carry the sick animal to veterinary hospitals from remote area.

Table 3. Availability of veterinary services to the respondents living near and far from upazila headquarter

\begin{tabular}{|c|c|c|c|}
\hline \multirow[t]{2}{*}{ Aspects of veterinary services } & \multicolumn{3}{|c|}{$\begin{array}{c}\text { Service Availability Index and percentage of respondents } \\
\text { received services }\end{array}$} \\
\hline & $\begin{array}{l}\text { Around upazila } \\
(\mathrm{N}=240)\end{array}$ & $\begin{array}{l}\text { Far from upazila } \\
(\mathrm{N}=240)\end{array}$ & Total $(\mathrm{N}=480)$ \\
\hline Disease diagnosis and treatment & $2.70(99.7 \%)$ & $2.42(100 \%)$ & $2.52(99.8 \%)$ \\
\hline Advice and general consultation & $2.16(87.0 \%)$ & $1.22(56.1 \%)$ & $1.67(70.9 \%)$ \\
\hline Surgery, obstetrics and gynaecological services & $0.61(32.8 \%)$ & $0.15(12.9 \%)$ & $0.30(22.4 \%)$ \\
\hline Disease prevention by vaccination & $0.79(42.8 \%)$ & $0.40(22.0 \%)$ & $0.59(32.1 \%)$ \\
\hline Availability of medicine (supply and purchase) & $2.79(100 \%)$ & $2.58(100 \%)$ & $2.68(100 \%)$ \\
\hline Artificial insemination & $0.13(8.8 \%)$ & $0.04(3.5 \%)$ & $0.08(6.0 \%)$ \\
\hline
\end{tabular}

In all four upazilas (study areas), situation seemed to have more or less same in regards of availability of veterinary services and the researchers made a firm conclusion that distance and transportation facilities were vital to availability of veterinary services to the rural people. Unless the veterinary services come to a reachable 
distance to the villagers, they will not go to the upazila headquarter to take these services. Study of Rahman and Jahan (2003) also showed that by using its services network and limited field staff DLS could provide effective

Availability of animal health services in rural areas

preventive services to only 10 per cent of the ruminants and treatments to around 13 per cent of the ruminants belonging to all category stakeholders. Thus service delivery at grassroots level was inadequate, ineffective and lacked needed level of frequency. The people who were most deprived of these services lived in remote areas.

It was found that almost all of the respondents in the study areas used to receive some sorts of animal health services in respect of treatment and availability of medicines. However, it was observed that except from general consultation and disease diagnosis and treatment, only few villagers received other important services on health and productivity. It seemed that MFTS project beneficiaries received higher level veterinary services than the non-beneficiaries in the study areas. On the other hand, farmers residing in the remote areas received much lower level services regarding all types of veterinary services. Planned motivational and awareness building programmes are needed to make people more interested in receiving animal health services provided by Department of Livestock Services and other sources. At the same time, in order to mitigate distance and transportation related problems, it is imperative for the government to provide door step level services (union level) for the villagers of the country. These are two most important recommendation of the study towards significant development of livestock sector of the country.

\section{ACKNOWLEDGEMENT}

This paper is a part of the research project entitled "Need Assessment on Veterinary Services: Availability and Cost of Animal Health Services in MFTS Project Areas" funded by Micro-Finance and Technical Support (MFTS) Project, supported by the International Fund for Agricultural Development (IFAD) and Palli-Karma Sahayak Foundation (PKSF).

\section{REFERENCES}

1. Bangladesh Economic Review (2010). Finance Division, Ministry of Finance, Govt. of the People’s Republic of Bangladesh, Dhaka.

2. Bangladesh National Livestock Development Policy (2007). Ministry of Fisheries and Livestock, Govt. of the People's Republic of Bangladesh, Dhaka.

3. Bangladesh National Livestock Extension policy (2013). Ministry of Fisheries and Livestock, Govt. of the People's Republic of Bangladesh, Dhaka.

4. Rahman H and Jahan N (2003). Livestock Services and the Poor in Bangladesh: A Case Study. A report submitted to Danish Agricultural Advisory Center, available at: http//: www.globallivestock.org.

5. Shamsuddin M, Alam MM, Hossein MS, Goodger WJ, Bari FY, Ahmed TU, Hossain MM and Khan AHMSI (2007). Participatory rural appraisal to identify needs and prospects of market-oriented dairy industries in Bangladesh. Tropical Animal Health and Production 39: 567-581.

6. Tareque AMM and Chowdhury SMZH (2010). Agricultural Research Priority: Vision- 2030 and beyond, BARC,Farmgate, Dhaka.

7. Umali DL, Feder G and de Haan C (1994). Animal Health Services: Finding the Balance between Public and Private Delivery. World Bank Research Observer 9 (1). 